\title{
Alkaline-earth metal fluoroalkoxide complexes with multi- coordinated polyether appendage: synthesis and characterization
}

\author{
Yun Chi ${ }^{\mathrm{a}, *}$, Sudhir Ranjan ${ }^{\mathrm{a}}$, Po-Wen Chung ${ }^{\mathrm{a}}$, Hsi-Ying Hsieh ${ }^{\mathrm{b}}$, Shie-Ming Peng ${ }^{\mathrm{c}}$, \\ Gene-Hsiang Lee ${ }^{\mathrm{c}}$ \\ ${ }^{a}$ Department of Chemistry, National Tsing Hua University, Hsinchu 30013, Taiwan, ROC \\ ${ }^{\mathrm{b}}$ Chung Hwa College of Medical Technology, Tainan 717, Taiwan, ROC \\ ${ }^{\mathrm{c}}$ Department of Chemistry and Instrumentation Center, National Taiwan University, Taipei 107, Taiwan, ROC
}

Received 1 October 2001; accepted 23 January 2002

\begin{abstract}
Four alkaline-earth metal alkoxide complexes of formula $\left[\mathrm{M}(\mathrm{meak})_{2}\right](\mathbf{1}, \mathrm{M}=\mathrm{Sr} ; \mathbf{2}, \mathrm{M}=\mathrm{Ba})$ and $\left[\mathrm{M}(\mathrm{biak})_{2}\right]_{2}(\mathbf{3}, \mathrm{M}=\mathrm{Sr} ; \mathbf{4}, \mathrm{M}=$ $\mathrm{Ba}$ ) were synthesized by the reaction of polyether substituted flouroalcohols, (meak) $\mathrm{H}=\mathrm{HOC}\left(\mathrm{CF}_{3}\right)_{2} \mathrm{CH}_{2}\left(\mathrm{OCH}_{2} \mathrm{CH}_{2}\right)_{2} \mathrm{OMe}_{2}$ and (biak) $\mathrm{H}=\mathrm{HOC}\left(\mathrm{CF}_{3}\right)_{2} \mathrm{CH}_{2} \mathrm{OCH}_{2} \mathrm{CH}_{2} \mathrm{~N}\left(\mathrm{CH}_{2} \mathrm{CH}_{2} \mathrm{OMe}\right)_{2}$, with metal source reagents $\mathrm{Sr}\left(\mathrm{OPr}^{\mathrm{i}}\right)_{2}$ and $\mathrm{BaH}_{2}$, respectively. These complexes were characterized by ${ }^{1} \mathrm{H}$ and ${ }^{19} \mathrm{~F}$ NMR spectroscopies and single crystal X-ray diffraction studies. The coordination geometry of $\mathbf{1}$ is best described as distorted trigonal dodecahedron, while complex $\mathbf{2}$ shows a similar coordination geometry, but possesses a $\mathrm{H}_{2} \mathrm{O}$ solvate linked to the alkoxy oxygen atom of the chelating meak ligands through H-bonding. Complexes [ $\left.\mathrm{Sr}(\text { biak })_{2}\right]_{2}$ (3) and $\left[\mathrm{Ba}(\text { biak })_{2}\right]_{2}(4)$ exist as dimers in the solid state in which the metal centers are linked by two bridging alkoxy oxygen atoms and encapsulated by a total of nine heteroatoms composed of a distorted tricapped trigonal prismatic geometry. Variable temperature ${ }^{19} \mathrm{~F}$ NMR studies of all complexes show simultaneous existence of two isomers in solution. Pyrolysis of these four complexes in air affords the expected $\mathrm{SrF}_{2}$ and $\mathrm{BaF}_{2}$ powders. (C) 2002 Elsevier Science B.V. All rights reserved.
\end{abstract}

Keywords: Crystal structures; Alkaline-earth metal complexes; Fluoroalkoxide complexes; Polyether complexes

\section{Introduction}

The design and synthesis of volatile compounds of Group 2 metal have recently generated considerable attraction because of the need for these compounds as MOCVD precursors for the preparation of metalcontaining oxide or fluoride thin films [1,2]. Enhanced volatility and suitable thermal stability, accomplished by the formation of saturated metal environment, are two of the most essential requirements for the better performance of these CVD precursors. Addition of ancillary ligands with sufficient oxygen or nitrogen donor atoms to a formally unsaturated metal complex is a method to achieve coordinative saturation. For example, crown ether, glyme and polyamine based chelate molecules have been successfully employed in

* Corresponding author. Fax: +886-3-572 0864.

E-mail address: ychi@mx.nthu.edu.tw (Y. Chi). improving the volatility of the Group 2 metal complexes [3]. However, the ensuing complexes may readily lose their donor ligand upon attempted sublimation, and this behavior would subsequently reduce its stability upon sublimation or vaporization. The second approach includes direct incorporation of the required multiple chelating features into the specially designed anionic ligands, so that their multiple bonding characteristics can fully satisfy the coordination requirement of the central cation, and addition of the second donor ligand is no longer needed. This strategy has led to the isolation of several polydentate oligoether alcoholate complexes or $\beta$-ketoiminate complexes involving polyether appendage that possess the enhanced stability [4].

In this paper, we wish to report the synthesis and structural characterization of four alkaline-earth metal complexes $\left[\mathrm{M}(\text { meak })_{2}\right](\mathbf{1}, \mathrm{M}=\mathrm{Sr} ; \mathbf{2}, \mathrm{M}=\mathrm{Ba})$ and $\left[\mathrm{M}(\text { biak })_{2}\right]_{2} \quad(\mathbf{3}, \mathrm{M}=\mathrm{Sr} ; \mathbf{4}, \mathrm{M}=\mathrm{Ba})$ with polyether substituted alcoholate ligands, meak $=\mathrm{OC}\left(\mathrm{CF}_{3}\right)_{2}$ $\mathrm{CH}_{2}\left(\mathrm{OCH}_{2} \mathrm{CH}_{2}\right)_{2} \mathrm{OMe}$ and biak $=\mathrm{OC}\left(\mathrm{CF}_{3}\right)_{2} \mathrm{CH}_{2-}$ 
$\mathrm{OCH}_{2} \mathrm{CH}_{2} \mathrm{~N}\left(\mathrm{CH}_{2} \mathrm{CH}_{2} \mathrm{OMe}\right)_{2}$. It is notable that both ligands not only possess a more reactive, acidic hydroxyl group due to the presence of two electron-withdrawing $\mathrm{CF}_{3}$ groups, but also contain at least three additional donor atoms on the side chains that can provide the desirable chelating interaction. Thus the reactions with the alkaline-earth metal sources would provide an easy access to the required metal complexes.

\section{Experimental}

\subsection{General information and materials}

Mass spectra were obtained on a JEOL SX-102A instrument operating in electron impact (EI) mode. ${ }^{1} \mathrm{H}$, ${ }^{13} \mathrm{C}$ and ${ }^{19} \mathrm{~F}$ NMR spectra were recorded on Varian Mercury-400 or Inova-500 instruments; chemical shifts are quoted with respect to internal standard TMS for ${ }^{1} \mathrm{H}$ and ${ }^{13} \mathrm{C}$ NMR and $\mathrm{CFCl}_{3}$ for ${ }^{19} \mathrm{~F}$ NMR data. Metal reagents $\mathrm{Sr}\left(\mathrm{OPr}^{\mathrm{i}}\right)_{2}$ and $\mathrm{BaH}_{2}$ were purchased from Strem Chemicals and used as received. All reactions were performed under a nitrogen atmosphere using deoxygenated solvents dried with an appropriate drying reagent. Elemental analyses were carried out at the NSC Regional Instrumentation Center at National Cheng Kung University, Tainan, Taiwan. TGA experiments were carried out on a Seiko SSC 5000 instrument under nitrogen or in air with a flow rate of $100 \mathrm{sccm}$.

\subsection{Synthesis of (meak)H}

To a $250 \mathrm{ml}$ reaction flask, $2.23 \mathrm{~g}(93 \mathrm{mmol})$ of $\mathrm{NaH}$ was suspended in $125 \mathrm{ml}$ ether. To this was added dropwise 2-(2-methoxyethoxy)ethanol $(9.60 \mathrm{~g}, 80 \mathrm{mmol})$ at $0{ }^{\circ} \mathrm{C}$. The mixture was stirred for $1 \mathrm{~h}$ at room temperature (r.t.) until the evolution of $\mathrm{H}_{2}$ ceased. The fluorinated oxirane $\left(\mathrm{CF}_{3}\right)_{2} \mathrm{COCH}_{2}$ (as synthesized from hexafluoroacetone and diazomethane ethereal solution) was added to the ether solution of the sodium salt of 2(2-methoxyethoxy)ethanol at $0{ }^{\circ} \mathrm{C}$, and the resulting mixture was stirred overnight at r.t. The reaction mixture was then poured into a saturated $\mathrm{NaHCO}_{3}$ solution at $0{ }^{\circ} \mathrm{C}(75 \mathrm{ml})$. The aqueous layer was extracted with $\mathrm{CH}_{2} \mathrm{Cl}_{2}$ twice $(2 \times 40 \mathrm{ml})$. The combined organic phase was dried over anhydrous $\mathrm{MgSO}_{4}$ and the solvent evaporated in vacuo. Finally, the residue was distilled under reduced pressure to give $13.0 \mathrm{~g}$ of colorless liquid $\left(54 \%\right.$, b.p. $=66{ }^{\circ} \mathrm{C}$ at 550 mtorr).

\subsubsection{Selected spectral data}

${ }^{1} \mathrm{H} \mathrm{NMR}\left(400 \mathrm{MHz}, \mathrm{CDCl}_{3}\right): \delta 5.75(\mathrm{~s}, 1 \mathrm{H}, \mathrm{OH}), 3.90$ (s, 2H, $\left.\mathrm{CH}_{2}\right), 3.76\left(\mathrm{~m}, 2 \mathrm{H}, \mathrm{OCH}_{2}\right), 3.65\left(\mathrm{~m}, 4 \mathrm{H}, \mathrm{OCH}_{2}\right)$, $3.52\left(\mathrm{~m}, 2 \mathrm{H}, \mathrm{OCH}_{2}\right), 3.34(\mathrm{~s}, 3 \mathrm{H}, \mathrm{OMe}) .{ }^{13} \mathrm{C} \mathrm{NMR}(100$ $\left.\mathrm{MHz}, \mathrm{CDCl}_{3}\right): \delta 122.6\left(\mathrm{q},{ }^{1} J_{\mathrm{CF}}=288 \mathrm{~Hz}, \mathrm{CF}_{3}\right), 75.5$ (sept, $\left.{ }^{2} J_{\mathrm{CF}}=29.2 \mathrm{~Hz}, \mathrm{C}\left(\mathrm{CF}_{3}\right)_{2}\right), 72.6\left(\mathrm{CH}_{2}\right), 71.6\left(\mathrm{CH}_{2}\right)$,
$70.5\left(\mathrm{CH}_{2}\right), 70.4\left(\mathrm{CH}_{2}\right), 68.1\left(\mathrm{CH}_{2}\right), 58.8(\mathrm{Me}) .{ }^{19} \mathrm{~F} \mathrm{NMR}$ $\left(470 \mathrm{MHz}, \mathrm{CDCl}_{3}, 295 \mathrm{~K}\right): \delta-76.0(6 \mathrm{~F})$.

\subsection{Synthesis of (biak)H}

Same as above except bis-(2-methoxyethyl)aminoethanol was taken in place of 2-(2-methoxyethoxy)ethanol, giving $16.3 \mathrm{~g}$ of colorless liquid $(57 \%$, b.p. $=$ $90{ }^{\circ} \mathrm{C}$ at 400 mtorr).

\subsubsection{Selected spectral data}

${ }^{1} \mathrm{H}$ NMR $\left(400 \mathrm{MHz}, \mathrm{CDCl}_{3}\right): \delta 3.90\left(\mathrm{~s}, 2 \mathrm{H}, \mathrm{CH}_{2}\right)$, $3.71\left(\mathrm{t},{ }^{3} J_{\mathrm{HH}}=5.6 \mathrm{~Hz}, 2 \mathrm{H}, \mathrm{OCH}_{2}\right), 3.52\left(\mathrm{t},{ }^{3} J_{\mathrm{HH}}=5.6\right.$ $\left.\mathrm{Hz}, 4 \mathrm{H}, \mathrm{OCH}_{2}\right), 3.28(\mathrm{~s}, 6 \mathrm{H}, \mathrm{OMe}), 2.82(\mathrm{~m}, 2 \mathrm{H}$, $\left.\mathrm{NCH}_{2}\right), 2.80\left(\mathrm{t},{ }^{3} J_{\mathrm{HH}}=5.6 \mathrm{~Hz}, 4 \mathrm{H}, \mathrm{NCH}_{2}\right) .{ }^{13} \mathrm{C} \mathrm{NMR}$ $\left(100 \mathrm{MHz}, \mathrm{CDCl}_{3}\right): \delta 122.9\left(\mathrm{q},{ }^{1} J_{\mathrm{CF}}=288 \mathrm{~Hz}, \mathrm{CF}_{3}\right)$, 76.1 (sept, $\left.{ }^{2} J_{\mathrm{CF}}=27.7 \mathrm{~Hz}, \mathrm{C}\left(\mathrm{CF}_{3}\right)_{2}\right), 70.3\left(\mathrm{CH}_{2}\right), 70.0$ $\left(\mathrm{CH}_{2}\right), 68.4\left(\mathrm{CH}_{2}\right), 58.6(\mathrm{Me}), 54.6\left(\mathrm{CH}_{2}\right), 53.5\left(\mathrm{CH}_{2}\right)$. ${ }^{19} \mathrm{~F}$ NMR $\left(470 \mathrm{MHz}, \mathrm{CDCl}_{3}, 295 \mathrm{~K}\right): \delta-76.6(6 \mathrm{~F})$.

\subsection{Synthesis of $\left[\mathrm{Sr}(\mathrm{meak})_{2}\right](\mathbf{1})$}

Strontium isopropoxide $(0.46 \mathrm{~g}, 2.24 \mathrm{mmol})$ in THF $(15 \mathrm{ml})$ was taken in a $100 \mathrm{ml}$ flask equipped with a condenser. To this was added $1.34 \mathrm{~g}$ of (meak)H (4.47 $\mathrm{mmol}$ ) dissolved in $30 \mathrm{ml}$ of THF, and the solution was brought to reflux. After $1 \mathrm{~h}$, a clear solution was obtained and the product started to precipitate as white crystalline powder during the period of $48 \mathrm{~h}$. In order to obtain X-ray quality crystals, the reaction was carried out in a highly diluted THF solution without stirring. Under this condition, the product complex precipitated out as single crystals upon cooling. The solvent was then decanted and the solid collected under $\mathrm{N}_{2}$, giving $1.15 \mathrm{~g}$ of $\left[\operatorname{Sr}(\text { meak })_{2}\right](1,1.68 \mathrm{mmol}, 76 \%)$.

\subsubsection{Spectral data of $\mathbf{1}$}

MS (EI, $\left.70 \mathrm{eV}, m / e^{+}, \mathrm{L}=\mathrm{C}_{9} \mathrm{H}_{13} \mathrm{~F}_{6} \mathrm{O}_{4}\right)$, observed (actual) \{relative abundance\} [assignment]: 793 (793) $\{10.0\}\left[\mathrm{SrL}_{2}+\mathrm{SrF}\right], 687$ (686) $\{7.7\}\left[\mathrm{SrL}_{2}\right], 617$ (617) $\{6.6\}\left[\mathrm{SrL}_{2}-\mathrm{CF}_{3}\right], 520(520)\{5.4\}\left[\mathrm{SrL}_{2}-\mathrm{C}_{3} \mathrm{~F}_{6} \mathrm{O}\right], 387$ (387) $\{100\}[\mathrm{SrL}], 317(318)\{79.4\} \quad\left[\mathrm{SrL}-\mathrm{CF}_{3}\right], 195$ (196) $\{3.1\}\left[\mathrm{L}-\mathrm{C}_{5} \mathrm{H}_{11} \mathrm{O}_{2}\right], 107$ (107) $\{14.6\}[\mathrm{SrF}] .{ }^{1} \mathrm{H}$ NMR (400 MHz, DMSO-d 6 ): $\delta 3.58\left(\mathrm{~s}, 2 \mathrm{H}, \mathrm{CH}_{2}\right), 3.54$ $\left(\mathrm{m}, 6 \mathrm{H}, \mathrm{OCH}_{2}\right), 3.44\left(\mathrm{~m}, 2 \mathrm{H}, \mathrm{OCH}_{2}\right), 3.25$ (s, 3H, OMe). ${ }^{13} \mathrm{C}$ NMR $\left(100 \mathrm{MHz}, \mathrm{DMSO}-\mathrm{d}_{6}\right): \delta 126.0\left(\mathrm{q},{ }^{1} J_{\mathrm{CF}}=296\right.$ $\left.\mathrm{Hz}, \mathrm{CF}_{3}\right), 80.4$ (sept, $\left.{ }^{2} J_{\mathrm{CF}}=25.6 \mathrm{~Hz}, \mathrm{C}\left(\mathrm{CF}_{3}\right)_{2}\right), 72.9$ $\left(\mathrm{CH}_{2}\right), 71.1\left(\mathrm{CH}_{2}\right), 70.0\left(\mathrm{CH}_{2}\right), 69.4\left(\mathrm{CH}_{2}\right), 69.4\left(\mathrm{CH}_{2}\right)$, $58.1(\mathrm{Me}) .{ }^{19} \mathrm{~F}$ NMR $\left(470 \mathrm{MHz}, \mathrm{DMF}_{-} \mathrm{d}_{7}, 295 \mathrm{~K}\right): \delta-$ $76.71(6 \mathrm{~F})$. Anal. Calc. for $\mathrm{C}_{18} \mathrm{H}_{26} \mathrm{~F}_{12} \mathrm{O}_{8} \mathrm{Sr}: \mathrm{C}, 31.52 ; \mathrm{H}$, 3.82. Found: C, 31.64; H, 3.94\%.

\subsection{Synthesis of [Ba(meak) $\left.{ }_{2}\right]$ (2)}

Barium hydride $(0.29 \mathrm{~g}, 2.08 \mathrm{mmol})$ was suspended in $\mathrm{C}_{7} \mathrm{H}_{16}(40 \mathrm{ml})$ in a $100 \mathrm{ml}$ reaction flask. To this was 
added $1.25 \mathrm{~g}$ of (meak)H $(4.16 \mathrm{mmol})$ dissolved in $10 \mathrm{ml}$ of THF. The mixture was then stirred at r.t. for $2 \mathrm{~h}$ and the solution was filtered to remove the insoluble materials. The filtrate was kept at r.t. for 4 days to allow crystallization of the product, giving $0.755 \mathrm{~g}$ of $\left[\mathrm{Ba}(\mathrm{meak})_{2}\right](\mathbf{2}, 1.02 \mathrm{mmol}, 49 \%)$ as colorless crystalline material.

\subsubsection{Spectral data of $\mathbf{2}$}

MS (EI, $70 \mathrm{eV}, m / e^{+}, \mathrm{L}=\mathrm{C}_{9} \mathrm{H}_{13} \mathrm{~F}_{6} \mathrm{O}_{4}$ ), observed (actual) \{relative abundance\} [assignment]: 893 (893) $\{0.1\}\left[\mathrm{BaL}_{2}+\mathrm{BaF}\right], 737$ (736) $\{0.2\}\left[\mathrm{BaL}_{2}\right], 667$ (667) $\{4.8\}\left[\mathrm{BaL}_{2}-\mathrm{CF}_{3}\right], 570(570)\{14.7\}\left[\mathrm{BaL}_{2}-\mathrm{C}_{3} \mathrm{~F}_{6} \mathrm{O}\right]$, 437 (437) $\{100\}[\mathrm{BaL}], 367(368)\{26.6\}\left[\mathrm{BaL}-\mathrm{CF}_{3}\right], 157$ (157) $\{5.6\}[\mathrm{BaF}] .{ }^{1} \mathrm{H}$ NMR $\left(400 \mathrm{MHz}, \mathrm{CD}_{3} \mathrm{CN}\right): \delta 3.73$ (s, $\left.2 \mathrm{H}, \mathrm{CH}_{2}\right), 3.66\left(\mathrm{~m}, 6 \mathrm{H}, \mathrm{OCH}_{2}\right), 3.53\left(\mathrm{~m}, 2 \mathrm{H}, \mathrm{OCH}_{2}\right)$, $3.33(\mathrm{~s}, 3 \mathrm{H}, \mathrm{OMe}) .{ }^{13} \mathrm{C}$ NMR $\left(100 \mathrm{MHz}, \mathrm{CD}_{3} \mathrm{CN}\right): \delta$ $126.8\left(\mathrm{q},{ }^{1} J_{\mathrm{CF}}=294 \mathrm{~Hz}, \mathrm{CF}_{3}\right), 82.0\left(\mathrm{sept},{ }^{2} J_{\mathrm{CF}}=25.7\right.$ $\left.\mathrm{Hz}, \mathrm{C}\left(\mathrm{CF}_{3}\right)_{2}\right), 73.7\left(\mathrm{CH}_{2}\right), 72.2\left(\mathrm{CH}_{2}\right), 71.2\left(\mathrm{CH}_{2}\right), 70.4$ $\left(\mathrm{CH}_{2}\right), 70.2\left(\mathrm{CH}_{2}\right), 59.0(\mathrm{Me}) .{ }^{19} \mathrm{~F}$ NMR $(470 \mathrm{MHz}$, $\left.\mathrm{DMF}_{-}, 295 \mathrm{~K}\right): \delta-76.71$ (6F). Anal. Calc. for $\mathrm{C}_{18} \mathrm{H}_{26} \mathrm{BaF}_{12} \mathrm{O}_{8}$ : C, 29.39; $\mathrm{H}, 3.56$. Found: C, 29.05; $\mathrm{H}, 3.73 \%$.

\subsection{Synthesis of $\left[\mathrm{Sr}(\text { biak })_{2}\right]_{2}(3)$}

Strontium isopropoxide $(0.478 \mathrm{~g}, 2.32 \mathrm{mmol})$ in THF $(15 \mathrm{ml})$ was taken in a $100 \mathrm{ml}$ flask equipped with a condenser. To this was added $1.66 \mathrm{~g}$ of (biak)H (4.64 $\mathrm{mmol}$ ) and $30 \mathrm{ml}$ of THF. The resulting mixture was refluxed for $30 \mathrm{~h}$. After cooling the solution to r.t., the mixture was filtered and the filtrate evaporated to dryness. Recrystallization from a mixture of $\mathrm{CH}_{2} \mathrm{Cl}_{2}$ and $\mathrm{C}_{7} \mathrm{H}_{16}$ afforded $1.28 \mathrm{~g}$ of $\left[\mathrm{Sr}(\text { biak })_{2}\right]_{2}(3,1.73 \mathrm{mmol}$, $69 \%$ ) as colorless crystalline material.

\subsubsection{Spectral data of $\mathbf{3}$}

MS (EI, $70 \mathrm{eV}, m / e^{+}, \mathrm{L}=\mathrm{C}_{12} \mathrm{H}_{20} \mathrm{~F}_{6} \mathrm{NO}_{4}$ ), observed (actual) \{relative abundance\} [assignment]: 907 (907) $\{14.0\}\left[\mathrm{SrL}_{2}+\mathrm{SrF}\right], 801$ (800) $\{2.6\}\left[\mathrm{SrL}_{2}\right], 444$ (444) $\{100\}[\mathrm{SrL}], 374(375) \quad\{52.7\}\left[\mathrm{SrL}-\mathrm{CF}_{3}\right], 356(356)$ $\{1.7\}[\mathrm{L}], 312(311)\{51.4\}\left[\mathrm{L}-\mathrm{C}_{2} \mathrm{H}_{5} \mathrm{O}\right], 107$ (107) $\{7.2\}$ [SrF]. ${ }^{1} \mathrm{H}$ NMR $\left(400 \mathrm{MHz}, \mathrm{DMSO}-\mathrm{d}_{6}\right): \delta 3.56(\mathrm{~s}, 2 \mathrm{H}$, $\left.\mathrm{CH}_{2}\right), 3.48\left(\mathrm{t},{ }^{3} J_{\mathrm{HH}}=5.5 \mathrm{~Hz}, 2 \mathrm{H}, \mathrm{OCH}_{2}\right), 3.38(\mathrm{t}$, $\left.{ }^{3} J_{\mathrm{HH}}=5.5 \mathrm{~Hz}, 4 \mathrm{H}, \mathrm{OCH}_{2}\right), 3.24(\mathrm{~s}, 6 \mathrm{H}, \mathrm{OMe}), 2.67(\mathrm{t}$, $\left.{ }^{3} J_{\mathrm{HH}}=5.5 \mathrm{~Hz}, 4 \mathrm{H}, \mathrm{NCH}_{2}\right), 2.64\left(\mathrm{br}, \mathrm{m}, 2 \mathrm{H}, \mathrm{NCH}_{2}\right) .{ }^{13} \mathrm{C}$ NMR $\left(100 \mathrm{MHz}\right.$, DMSO-d $\left.{ }_{6}\right): \delta 126.0\left(\mathrm{q},{ }^{1} J_{\mathrm{CF}}=296\right.$ $\left.\mathrm{Hz}, \mathrm{CF}_{3}\right), 80.4$ (sept, $\left.{ }^{2} J_{\mathrm{CF}}=24.8 \mathrm{~Hz}, \mathrm{C}\left(\mathrm{CF}_{3}\right)_{2}\right), 72.6$ $\left(\mathrm{CH}_{2}\right), 69.8\left(\mathrm{CH}_{2}\right), 68.4\left(\mathrm{CH}_{2}\right), 58.1(\mathrm{Me}), 53.1\left(\mathrm{CH}_{2}\right)$, $52.4\left(\mathrm{CH}_{2}\right) .{ }^{19} \mathrm{~F}$ NMR $\left(470 \mathrm{MHz}, \mathrm{DMF}-\mathrm{d}_{7}, 295 \mathrm{~K}\right): \delta-$ 77.25 (6F). Anal. Calc. for $\mathrm{C}_{24} \mathrm{H}_{40} \mathrm{~F}_{12} \mathrm{~N}_{2} \mathrm{O}_{8} \mathrm{Sr}$ : C, 36.02; H, 5.04; N, 3.50. Found: C, 36.02; H, 4.92; N, 3.75\%.

\subsection{Synthesis of $\left[\mathrm{Ba}(\mathrm{biak})_{2}\right]_{2}(4)$}

Barium hydride $(0.43 \mathrm{~g}, 3.08 \mathrm{mmol})$ was taken in a $100 \mathrm{ml}$ flask equipped with a condenser. To this was added $2.0 \mathrm{~g}$ of (biak)H $(5.66 \mathrm{mmol})$. The resulting mixture was stirred at r.t. for $1 \mathrm{~h}$ until evolution of $\mathrm{H}_{2}$ gas stopped. Additional $50 \mathrm{ml}$ THF was then added and the mixture was brought to reflux. After $24 \mathrm{~h}$, the unreacted $\mathrm{BaH}_{2}$ was removed by filtration and the filtrate evaporated to dryness. The solid material was then purified by recrystallization from a mixture of $\mathrm{C}_{6} \mathrm{H}_{5} \mathrm{CH}_{3}$ and $\mathrm{C}_{7} \mathrm{H}_{16}$ at r.t., giving $1.69 \mathrm{~g}$ of $\left[\mathrm{Ba}(\text { biak })_{2}\right]_{2}$ $(4,1.99 \mathrm{mmol}, 71 \%)$ as colorless crystalline material.

\subsubsection{Spectral data of 4}

MS (EI, $70 \mathrm{eV}, m / e^{+}, \mathrm{L}=\mathrm{C}_{12} \mathrm{H}_{20} \mathrm{~F}_{6} \mathrm{NO}_{4}$ ), observed (actual) \{relative abundance\} [assignment]: 1007 (1007) $\{26.5\}\left[\mathrm{BaL}_{2}+\mathrm{BaF}\right], 851(850)\{14.8\}\left[\mathrm{BaL}_{2}\right], 494$ (494) $\{100\}[\mathrm{BaL}], 424$ (424) $\{69.1\}\left[\mathrm{BaL}-\mathrm{CF}_{3}\right], 356(356)$ $\{3.0\}[\mathrm{L}], 312(311)\{72.0\}\left[\mathrm{L}-\mathrm{C}_{2} \mathrm{H}_{5} \mathrm{O}\right], 157(157)\{21.6\}$ [BaF]. ${ }^{1} \mathrm{H}$ NMR $\left(400 \mathrm{MHz}\right.$, DMSO-d $\left.{ }_{6}\right): \delta 3.56(\mathrm{~s}, 2 \mathrm{H}$, $\left.\mathrm{CH}_{2}\right), 3.50\left(\mathrm{t},{ }^{3} J_{\mathrm{HH}}=5.6 \mathrm{~Hz}, 2 \mathrm{H}, \mathrm{OCH}_{2}\right), 3.39(\mathrm{t}$, $\left.{ }^{3} J_{\mathrm{HH}}=5.6 \mathrm{~Hz}, 4 \mathrm{H}, \mathrm{OCH}_{2}\right), 3.24(\mathrm{~s}, 6 \mathrm{H}, \mathrm{OMe}), 2.66(\mathrm{t}$, $\left.{ }^{3} J_{\mathrm{HH}}=5.6 \mathrm{~Hz}, 4 \mathrm{H}, \mathrm{NCH}_{2}\right), 2.63\left(\mathrm{br}, \mathrm{m}, 2 \mathrm{H}, \mathrm{NCH}_{2}\right) \cdot{ }^{13} \mathrm{C}$ NMR (100 MHz, DMSO-d 6$): \delta 125.9\left(\mathrm{q},{ }^{1} J_{\mathrm{CF}}=297\right.$ $\left.\mathrm{Hz}, \mathrm{CF}_{3}\right), 81.2$ (br, m, $\left.\mathrm{C}\left(\mathrm{CF}_{3}\right)_{2}\right), 72.9\left(\mathrm{CH}_{2}\right), 69.8\left(\mathrm{CH}_{2}\right)$, $68.6\left(\mathrm{CH}_{2}\right), 58.1(\mathrm{Me}), 53.0\left(\mathrm{CH}_{2}\right), 52.7\left(\mathrm{CH}_{2}\right) .{ }^{19} \mathrm{~F}$ NMR (470 MHz, DMF-d $7,295 \mathrm{~K}): \delta-77.17$. Anal. Calc. for $\mathrm{C}_{24} \mathrm{H}_{40} \mathrm{BaF}_{12} \mathrm{~N}_{2} \mathrm{O}_{8}$ : C, 33.92; $\mathrm{H}, 4.74 ; \mathrm{N}, 3.30$. Found: C, 34.00; H, 4.70; N, 3.53\%.

\subsection{X-ray crystallography}

X-ray diffraction data were measured on a Bruker SMART CCD diffractometer using $\lambda($ Mo $\mathrm{K} \alpha$ ) radiation $0.7107 \AA$ at a temperature of $150 \mathrm{~K}$. All the crystallographic data were collected over a hemisphere of reciprocal space, by a combination of three sets of exposures. Each set had a different $\varphi$ angle for the crystal and each exposure of $10 \mathrm{~s}$ covered $0.30^{\circ}$ in $\varphi$. The data collection was performed using the SMART program. An empirical absorption was based on the symmetry-equivalent reflections and applied the data using the SADABS program. The structure was solved using the SHELXTL-97 program [5]. The crystallographic refinement parameters of complexes 1-4 are summarized in Table 1, while their selected bond distances and angles are given in Tables $2-5$, respectively.

\section{Results and discussion}

\subsection{Synthesis}

The fluorinated polyether substituted alcohols (meak) $\mathrm{H}$ and (biak) $\mathrm{H}$ were prepared in good yields by 
Table 1

X-ray structural data of complexes 1-4

\begin{tabular}{|c|c|c|c|c|}
\hline Compounds & 1 & 2 & 3 & 4 \\
\hline Empirical formula & $\mathrm{C}_{18} \mathrm{H}_{26} \mathrm{~F}_{12} \mathrm{O}_{8} \mathrm{Sr}$ & $\mathrm{C}_{18} \mathrm{H}_{28} \mathrm{BaF}_{12} \mathrm{O}_{9}$ & $\mathrm{C}_{48} \mathrm{H}_{80} \mathrm{~F}_{24} \mathrm{~N}_{4} \mathrm{O}_{16} \mathrm{Sr}_{2}$ & $\mathrm{C}_{48} \mathrm{H}_{80} \mathrm{Ba}_{2} \mathrm{~F}_{24} \mathrm{~N}_{4} \mathrm{O}_{16}$ \\
\hline Molecular weight & 686.01 & 753.74 & 1600.40 & 1699.84 \\
\hline Temperature (K) & 150 & 150 & 150 & 150 \\
\hline Crystal system & monoclinic & monoclinic & triclinic & triclinic \\
\hline Space group & $C 2 / c$ & $C 2 / c$ & $P \overline{1}$ & $P \overline{1}$ \\
\hline$a(\AA)$ & $19.7922(5)$ & $19.9565(6)$ & $9.9374(3)$ & $10.0409(4)$ \\
\hline$b(\AA)$ & $9.9824(3)$ & $10.4416(3)$ & $10.8406(3)$ & $10.9508(5)$ \\
\hline$c(\AA)$ & $13.7548(4)$ & $13.7955(4)$ & $17.3458(5)$ & $17.5007(7)$ \\
\hline$\alpha\left({ }^{\circ}\right)$ & & & $96.515(1)$ & $96.681(1)$ \\
\hline$\beta\left({ }^{\circ}\right)$ & $106.369(1)$ & $112.827(1)$ & 106.193(1) & $105.561(1)$ \\
\hline$\gamma\left({ }^{\circ}\right)$ & & & $109.341(1)$ & $109.742(1)$ \\
\hline$V\left(\AA^{3}\right)$ & 2607.43(13) & 2649.53(13) & $1649.81(8)$ & $1698.75(12)$ \\
\hline$Z$ & 4 & 4 & 1 & 1 \\
\hline$D_{\text {calc }}\left(\mathrm{g} \mathrm{cm}^{-3}\right)$ & 1.748 & 1.890 & 1.611 & 1.662 \\
\hline$F(000)$ & 1376 & 1488 & 816 & 852 \\
\hline Crystal size (mm) & $0.25 \times 0.20 \times 0.10$ & $0.30 \times 0.30 \times 0.30$ & $0.35 \times 0.13 \times 0.10$ & $0.25 \times 0.10 \times 0.10$ \\
\hline Index ranges & $\begin{array}{l}-25 \leq h \leq 25 \\
-12 \leq k \leq 12,-17 \leq l \leq 17\end{array}$ & $\begin{array}{l}-25 \leq h \leq 25 \\
-13 \leq k \leq 13,-17 \leq l \leq 17\end{array}$ & $\begin{array}{l}-12 \leq h \leq 12,-14 \leq k \leq 14, \\
-22 \leq l \leq 22\end{array}$ & $\begin{array}{l}-13 \leq h \leq 13,-14 \leq k \leq 14 \\
-22 \leq l \leq 22\end{array}$ \\
\hline$\mu($ Mo $\mathrm{K} \alpha) \mathrm{mm}^{-1}$ & 2.194 & 1.628 & 1.748 & 1.280 \\
\hline $\begin{array}{l}\text { Max./min. trans- } \\
\text { mission }\end{array}$ & $0.7456,0.5847$ & $0.6942,0.5901$ & $0.8621,0.7169$ & $0.8621,0.7902$ \\
\hline Data/parameters & $2995 / 179$ & $3046 / 185$ & $7558 / 425$ & $7792 / 424$ \\
\hline $\begin{array}{l}R_{1}, w R_{2} \text { with } \\
{[I>2 \sigma(I)]}\end{array}$ & $0.024,0.058$ & $0.025,0.066$ & $0.046,0.119$ & $0.057,0.146$ \\
\hline $\begin{array}{l}\text { Extinction coeffi- } \\
\text { cient }\end{array}$ & $0.00064(18)$ & & $0.0027(9)$ & \\
\hline $\begin{array}{l}\text { D-map, max/min } \\
\left(\mathrm{e} \AA^{-3}\right)\end{array}$ & $0.543 /-0.374$ & $0.730 /-0.782$ & $2.966 /-0.749$ & $3.948 /-0.773$ \\
\hline
\end{tabular}

Table 2

Selected bond distances $(\AA)$ and angles $\left({ }^{\circ}\right)$ for complex 1

\begin{tabular}{lrlr}
\hline $\begin{array}{l}\text { Bond distances } \\
\mathrm{Sr}-\mathrm{O}(1)\end{array}$ & $2.662(1)$ & $\mathrm{Sr}-\mathrm{O}(2)$ & $2.709(1)$ \\
$\mathrm{Sr}-\mathrm{O}(3)$ & $2.595(2)$ & $\mathrm{Sr}-\mathrm{O}(4)$ & $2.407(2)$ \\
Bond angles & & & \\
$\mathrm{O}(1)-\mathrm{Sr}-\mathrm{O}(2)$ & $61.45(4)$ & $\mathrm{O}(2)-\mathrm{Sr}-\mathrm{O}(3)$ & $61.96(4)$ \\
$\mathrm{O}(3)-\mathrm{Sr}-\mathrm{O}(4)$ & $64.59(4)$ & $\mathrm{O}(1)-\mathrm{Sr}-\mathrm{O}(4)$ & $158.50(4)$ \\
$\mathrm{O}(1)-\mathrm{Sr}-\mathrm{O}(1 \mathrm{~A})$ & $76.24(4)$ & $\mathrm{O}(2)-\mathrm{Sr}-\mathrm{O}(2 \mathrm{~A})$ & $130.03(4)$ \\
$\mathrm{O}(3)-\mathrm{Sr}-\mathrm{O}(3 \mathrm{~A})$ & $144.33(4)$ & $\mathrm{O}(4)-\mathrm{Sr}-\mathrm{O}(4 \mathrm{~A})$ & $115.75(4)$ \\
\hline
\end{tabular}

Table 3

Selected bond distances $(\AA)$ and angles $\left({ }^{\circ}\right)$ for complex 2

\begin{tabular}{lrlr}
\hline Bond distances & & & \\
$\mathrm{Ba}-\mathrm{O}(1)$ & $2.835(2)$ & $\mathrm{Ba}-\mathrm{O}(2)$ & $2.899(2)$ \\
$\mathrm{Ba}-\mathrm{O}(3)$ & $2.774(3)$ & $\mathrm{Ba}-\mathrm{O}(4)$ & $2.597(2)$ \\
$\mathrm{Ba} \cdot \mathrm{O}(5)$ & $3.837(3)$ & $\mathrm{O}(4)-\mathrm{H}(5 \mathrm{C})$ & $1.968(4)$ \\
Bond angles & & & \\
$\mathrm{O}(1)-\mathrm{Ba}-\mathrm{O}(2)$ & $57.06(6)$ & $\mathrm{O}(2)-\mathrm{Ba}-\mathrm{O}(3)$ & $58.30(6)$ \\
$\mathrm{O}(3)-\mathrm{Ba}-\mathrm{O}(4)$ & $58.81(7)$ & $\mathrm{O}(1)-\mathrm{Ba}-\mathrm{O}(4)$ & $164.06(6)$ \\
$\mathrm{O}(1)-\mathrm{Ba}-\mathrm{O}(1 \mathrm{~A})$ & $67.34(6)$ & $\mathrm{O}(2)-\mathrm{Ba}-\mathrm{O}(2 \mathrm{~A})$ & $135.55(6)$ \\
$\mathrm{O}(3)-\mathrm{Ba}-\mathrm{O}(3 \mathrm{~A})$ & $139.76(6)$ & $\mathrm{O}(4)-\mathrm{Ba}-\mathrm{O}(4 \mathrm{~A})$ & $96.58(7)$ \\
\hline
\end{tabular}

direct reaction of the sodium salt of $\mathrm{HOCH}_{2} \mathrm{CH}_{2} \mathrm{OCH}_{2}-$ $\mathrm{CH}_{2} \mathrm{OMe}$ and $\mathrm{HOCH}_{2} \mathrm{CH}_{2} \mathrm{~N}\left(\mathrm{CH}_{2} \mathrm{CH}_{2} \mathrm{OMe}\right)_{2}$, and the fluorinated oxirane $\left(\mathrm{CF}_{3}\right)_{2} \mathrm{COCH}_{2}$ in diethylether solu-
Table 4

Selected bond distances $(\AA)$ and angles $\left({ }^{\circ}\right)$ for complex $\mathbf{3}$

\begin{tabular}{llll}
\hline Bond distances & & & \\
$\mathrm{Sr}(1)-\mathrm{O}(1)$ & $2.655(3)$ & $\mathrm{Sr}(1)-\mathrm{O}(2)$ & $2.830(3)$ \\
$\mathrm{Sr}(1)-\mathrm{O}(3)$ & $2.632(3)$ & $\mathrm{Sr}(1)-\mathrm{O}(4)$ & $2.538(3)$ \\
$\mathrm{Sr}(1)-\mathrm{N}(1)$ & $2.835(4)$ & $\mathrm{Sr}(1)-\mathrm{O}(8)$ & $2.337(3)$ \\
$\mathrm{Sr}(1)-\mathrm{O}(4 \mathrm{~A})$ & $2.524(3)$ & $\mathrm{Sr}(1)-\mathrm{F}(2 \mathrm{~A})$ & $3.133(4)$ \\
$\mathrm{Sr}(1)-\mathrm{F}(5 \mathrm{~A})$ & $3.140(4)$ & $\mathrm{Sr}(1) \cdots \mathrm{Sr}(1 \mathrm{~A})$ & $4.193(2)$ \\
Bond angles & & & \\
$\mathrm{O}(1)-\mathrm{Sr}(1)-\mathrm{O}(8)$ & $155.04(8)$ & $\mathrm{O}(2)-\mathrm{Sr}(1)-\mathrm{O}(4)$ & $174.75(7)$ \\
\hline
\end{tabular}

Table 5

Selected bond distances $(\AA)$ and angles $\left({ }^{\circ}\right)$ for complex 4

\begin{tabular}{llll}
\hline Bond distances & & & \\
$\mathrm{Ba}(1)-\mathrm{O}(1)$ & $2.821(5)$ & $\mathrm{Ba}(1)-\mathrm{O}(2)$ & $2.856(4)$ \\
$\mathrm{Ba}(1)-\mathrm{O}(3)$ & $2.816(4)$ & $\mathrm{Ba}(1)-\mathrm{O}(4)$ & $2.672(4)$ \\
$\mathrm{Ba}(1)-\mathrm{N}(1)$ & $2.975(5)$ & $\mathrm{Ba}(1)-\mathrm{O}(4 \mathrm{~A})$ & $2.654(4)$ \\
$\mathrm{Ba}(1)-\mathrm{F}(2 \mathrm{~A})$ & $3.358(6)$ & $\mathrm{Ba}(1)-\mathrm{F}(5 \mathrm{~A})$ & $3.212(4)$ \\
$\mathrm{Ba}(1)-\mathrm{O}(8)$ & $2.468(4)$ & $\mathrm{Ba}(1) \cdots \mathrm{Ba}(1 \mathrm{~A})$ & $4.356(2)$ \\
Bond angles & & & \\
$\mathrm{O}(2)-\mathrm{Ba}(1)-\mathrm{O}(4)$ & $174.14(11)$ & $\mathrm{O}(1)-\mathrm{Ba}(1)-\mathrm{O}(8)$ & $151.78(12)$ \\
\hline
\end{tabular}

tion. The latter is in-situ generated from hexafluoroacetone and diazomethane etherate at room temperature [6]. The general synthetic procedure is identical to that of related fluoro-aminoalcohol ligands $\mathrm{HO}\left(\mathrm{CF}_{3}\right)_{2}-$ 
$\mathrm{CH}_{2} \mathrm{NH}\left(\mathrm{CH}_{2} \mathrm{CH}_{2} \mathrm{OMe}\right)$ and $\mathrm{HO}\left(\mathrm{CF}_{3}\right)_{2} \mathrm{CH}_{2} \mathrm{~N}\left(\mathrm{CH}_{2}-\right.$ $\left.\mathrm{CH}_{2} \mathrm{OMe}\right)_{2}$, which have been utilized in preparation of the $\mathrm{Sr}(\mathrm{II}), \mathrm{Ba}$ (II) and $\mathrm{Cu}$ (II) CVD source reagents [7].

As indicated in Scheme 1, synthesis of the alkoxide complex $\left[\mathrm{Sr}(\mathrm{meak})_{2}\right]$ (1) was achieved by the treatment of $\mathrm{Sr}\left(\mathrm{OPr}^{\mathrm{i}}\right)_{2}$ with 2 equiv. of (meak)H in THF at reflux. Crystalline solid was immediately precipitated out of the solution during reaction and the pure product was collected by precipitation and washing with dry hexane. The related complex $\left[\mathrm{Ba}(\text { meak })_{2}\right](2)$ was synthesized in $\mathrm{THF}$-heptane $(1: 4)$ at room temperature in $50 \%$ yield using $\mathrm{BaH}_{2}$ as the metal source. Complex $\mathbf{1}$ is found to be insoluble in most organic solvents except polar solutions as DMF and DMSO; however, complex 2 is sparingly soluble in hydrocarbons such as hexane and toluene, but is much more soluble in dichloromethane and THF. Both complexes $\mathbf{1}$ and $\mathbf{2}$ are moisturesensitive and, thus, contact with air must be avoided while handling these complexes.

The dimer complexes $\left[\mathrm{Sr}(\text { biak })_{2}\right]_{2}(3)$ and $\left[\mathrm{Ba}(\text { biak })_{2}\right]_{2}$ (4) were prepared by the reaction of (biak)H with the reagents $\mathrm{Sr}\left(\mathrm{OPr}^{\mathrm{i}}\right)_{2}$ or $\mathrm{BaH}_{2}$ under a similar condition. These dimer complexes are found to be much soluble in common solvents and are less sensitive to moisture upon exposure to air. It appears that the large hydrophobic groups of the biak ligand have provided a better shielding effect against the attack by moisture that would lead to the unwanted hydrolysis and sample decomposition.

\subsection{Mass spectra}

All mass spectral data show a similar pattern of fragmentation. The most intense mass fragment corresponds to $[\mathrm{BaL}]^{+}$or $[\mathrm{SrL}]^{+}$ions which is produced by elimination of one anionic ligand, a result of the electron bombardment. Other fragments such as $\left[\mathrm{ML}-\mathrm{CF}_{3}\right]^{+}$ and $[\mathrm{MF}]^{+}$are observed in the spectra. Besides these signals, a weak signal deriving from the molecular ion
(1) $M=S r ;(2) M=B a$

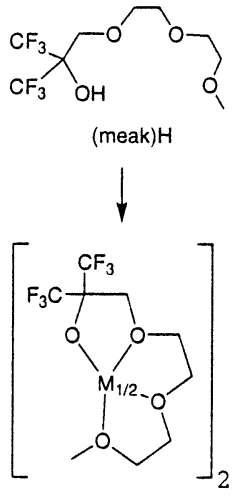

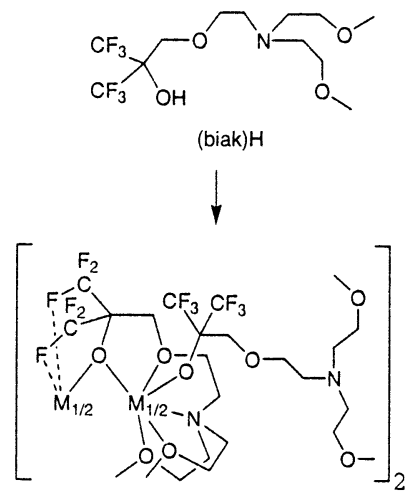

(3) $M=S r$; (4) $M=B a$
Scheme 1.
$\left[\mathrm{ML}_{2}\right]^{+}$is observed, while the daughter ions such as $\left[\mathrm{ML}_{2}-\mathrm{CF}_{3}\right]^{+}$and $\left[\mathrm{ML}_{2}-\mathrm{C}_{3} \mathrm{~F}_{6} \mathrm{O}\right]^{+}$are only present in the spectra of $\mathbf{1}$ and $\mathbf{2}$, but not for the spectra of $\mathbf{3}$ and $\mathbf{4}$, suggesting that the latter may possess a stronger coordination capability that can prevent the fragmentation of the parent ion $\left[\mathrm{ML}_{2}\right]^{+}$. Moreover, the metal fragment with $m / e$ value greater than that of the parent molecular ion $\left[\mathrm{ML}_{2}\right]^{+}$is the $\left[\mathrm{ML}_{2}+\mathrm{MF}\right]^{+}$ion, albeit in a very low intensity.

\section{3. $X$-ray structures of 1 and 2}

The single-crystal X-ray structure of complex $\mathbf{1}$ is shown in Fig. 1 and the bond distances and angles are compiled in Table 2 . The complex crystallizes in the space group $C 2 / c$ and possesses a twofold rotation axis passing the central metal cation. The $\mathrm{Sr}$ atom is eightcoordinated and bonded to two meak ligands through all the available oxygen donor atoms. The $\mathrm{Sr}-\mathrm{O}(4)$ distance $(2.407(2) \AA)$ is found to be appreciably shorter than the respective $\mathrm{Sr}-\mathrm{O}$ (ether) distances, $\mathrm{Sr}-\mathrm{O}(1)=$ 2.662(1), $\mathrm{Sr}-\mathrm{O}(2)=2.709(1)$ and $\mathrm{Sr}-\mathrm{O}(3)=2.595(2)$ $\AA$, suggesting that the negatively charged alkoxy oxygen is bonded more strongly to the $\mathrm{Sr}$ metal center. For comparison, the $\mathrm{Sr}-\mathrm{O}(4)$ distance is slightly shorter than those found in the $\beta$-diketonate complexes $\left[\mathrm{Sr}(\mathrm{thd})_{2}\{\operatorname{tris}(2\right.$-aminoethylene $)$ amine $\left.\}\right] \quad(\mathrm{Sr}-\mathrm{O}(\mathrm{thd})=$ $2.466(7)-2.656(7) \AA)[8],\left[\mathrm{Sr}(\mathrm{tfpd})_{4}\right]^{2-}(\mathrm{Sr}-\mathrm{O}(\mathrm{tfpd})=$ $2.530(2)-2.593(2) \quad \AA) \quad[9], \quad\left[\operatorname{Sr}(\mathrm{hfac})_{2}(\mathrm{bpy})_{2}\right] \quad(\mathrm{Sr}-$ $\mathrm{O}(\mathrm{hfac})=2.532(5)-2.559(5) \AA)[10]$ and $\left[\mathrm{Sr}(\mathrm{hfac})_{2}\right.$ (triglyme)] (average $\mathrm{Sr}-\mathrm{O}(\mathrm{hfac})=2.521 \AA$ ) [11], and the polymetallic complexes $\left[\mathrm{Sr}_{3}(\text { thd })_{6}(\mathrm{Hthd})\right]$ [12], (average $\mathrm{Sr}-\mathrm{O}($ diket $)=2.498 \AA$ ) $)$ and $\left[\mathrm{Sr}_{4}(\mathrm{OPh})_{8}(\mathrm{PhOH})_{2}(\text { thf })_{6}\right]$ (average $\mathrm{Sr}-\mathrm{O}($ alk $)=2.450 \AA$ ) [13].

Moreover, the immediate coordination geometry of the $\mathrm{Sr}$ metal center in $\mathbf{1}$ is a distorted dodecahedral. This is represented by two interpenetrating tetrahedrons, one is defined by the atoms $\mathrm{O}(3), \mathrm{O}(3 \mathrm{~A}), \mathrm{O}(1)$ and $\mathrm{O}(1 \mathrm{~A})$ and the second by the atoms $\mathrm{O}(4), \mathrm{O}(4 \mathrm{~A}), \mathrm{O}(2)$ and

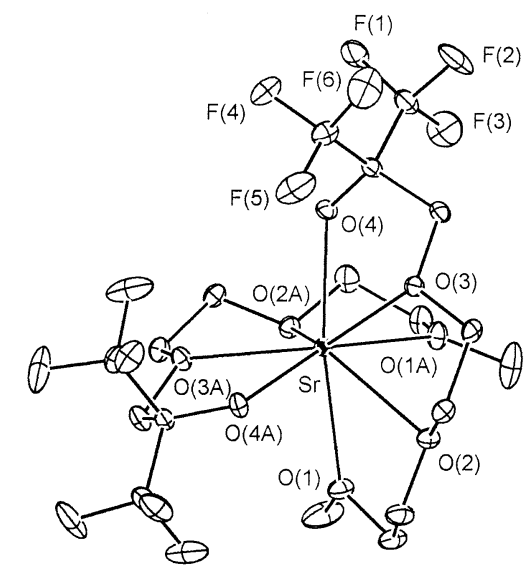

Fig. 1. ORTEP drawing of $\mathbf{1}$ with thermal ellipsoids shown at the $30 \%$ probability level. 
$\mathrm{O}(2 \mathrm{~A})$. Alternatively, the key feature of this geometry may be revealed using two trapezoidal planes, defined by the atoms $\mathrm{O}(4), \mathrm{O}(3), \mathrm{O}(2)$ and $\mathrm{O}(1)$ and the atoms $\mathrm{O}(4 \mathrm{~A}), \mathrm{O}(3 \mathrm{~A}), \mathrm{O}(2 \mathrm{~A})$ and $\mathrm{O}(1 \mathrm{~A})$, respectively. As these intersecting trapezoidal planes show a dihedral angle of $87.2^{\circ}$, which is very close to the value predicted by a perfect dodecahedron, i.e. $90^{\circ}$, we can then identify the proposed dodecahedral geometry. Finally, the dihedral angles between the planes $\mathrm{O}(3)-\mathrm{Sr}-\mathrm{O}(4)$ and $\mathrm{O}(3 \mathrm{~A})-$ $\mathrm{Sr}-\mathrm{O}(4 \mathrm{~A})$ is $114.8^{\circ}$ which has been greatly deviated from the angle of the intersecting trapezoidal planes discussed earlier, showing a large steric repulsion between two inner $\mathrm{CF}_{3}$ groups of the alkoxide ligands.

For the barium complex 2, the metal center is also encircled by two chelating ligands similar to that found in 1 (Fig. 2). In this case the bonding mode of meak ligands is similar to the pattern found in polyamine or polyglyme adduct of barium $\beta$-diketonate complexes, which also exhibit the eight- or ten-coordinated geometry [14]. The $\mathrm{Ba}-\mathrm{O}(4)$ distance in 2 is 2.597(2) $\AA$, showing a distance comparable to the alkoxide [15] or aryloxide complexes such as $\left[\mathrm{Ba}_{2}\left(\mathrm{OCPh}_{3}\right)_{4}(\mathrm{THF})_{3}\right]$ [16] (average $\mathrm{Ba}-\mathrm{O}=2.601 \AA$ ) and $\left[\mathrm{Ba}(\mathrm{OPh})_{2}(18\right.$-crown-6)] $(\mathrm{Ba}-\mathrm{O}=2.570(8) \AA)$ [17]. The $\mathrm{Ba}-\mathrm{O}($ ether) distances of 2 range from 2.774(3) to 2.899(2) $\AA$ which are comparable to those of the typical $\mathrm{O} \rightarrow \mathrm{Ba}$ dative bonds $[14,15]$. In addition, one water molecule has been found to reside close to the complex with non-bonding distance $\mathrm{Ba} \cdots \mathrm{O}(5)=3.837(3) \AA$, and exhibited two significant $\mathrm{H}$-bonding interactions to the nearby alkoxide oxygen atom $(\mathrm{O}(4)-\mathrm{H}(5 \mathrm{C})=1.968(4) \AA)$. As a result, a slight distortion of the central metal core is expected. This minute change of coordination geometry is evident by reduction of the $\mathrm{O}(4)-\mathrm{Ba}-\mathrm{O}(4 \mathrm{~A})$ angle $\left(96.58(7)^{\circ}\right)$ with respect to that of the $\mathrm{O}(4)-\mathrm{Sr}-\mathrm{O}(4 \mathrm{~A})$ angle observed in $1\left(115.75(4)^{\circ}\right)$, where no coordinated water molecule was observed in the crystal structure.

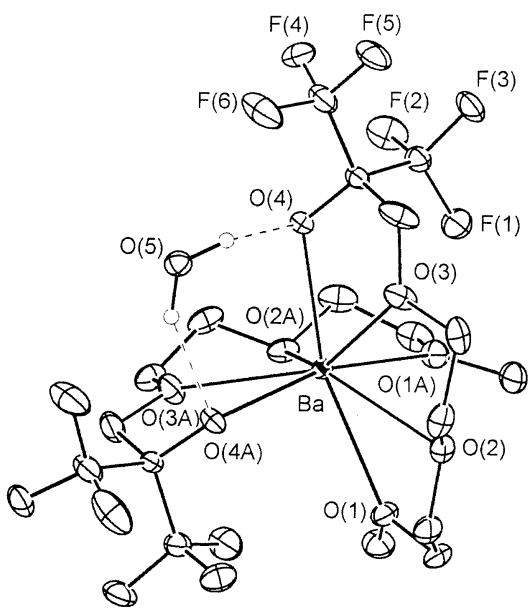

Fig. 2. ORTEP drawing of $\mathbf{2}$ with thermal ellipsoids shown at the $30 \%$ probability level.

\section{4. $X$-ray structures of 3 and 4}

The single crystal X-ray structure of complexes 3 and 4 is shown in Figs. 3 and 4 and selected bond distances and angles are given in Tables 4 and 5, respectively. In contrast to that of $\mathbf{1}$ and $\mathbf{2}$, they exist as centrosymmetric dimers with two alkoxy oxygen atoms linking between two non-bonded strontium or barium metal atoms.

In complex 3, each metal center adopts a ninecoordinate, distorted tricapped trigonal prism, for which the triangular planes of the trigonal prism are defined by the atoms $\mathrm{O}(1), \mathrm{O}(4)$ and $\mathrm{O}(4 \mathrm{~A})$ and the atoms $\mathrm{N}(1)$, $\mathrm{O}(2)$ and $\mathrm{O}(8)$, respectively; while the capping atoms at each of the square faces are the atoms $\mathrm{O}(3), \mathrm{F}(5 \mathrm{~A})$ and $\mathrm{F}(2 \mathrm{~A})$.

On the other hand, if we focus only on the arrangement of ligands, two distinctive types of bonding are clearly observed in this dimer molecule. The first one shows a terminal bonding mode and it is linked to the $\mathrm{Sr}$ metal atom through its alkoxy oxygen atom $\mathrm{O}(8)$, while other four heteroatoms on the backbone of ligand reside at the outer periphery of the complex and show no direct bonding to the metal atom. In striking contrast to this terminal ligand, the second alkoxide ligand is coordinated to one metal cation using the unique nitrogen atom $\mathrm{N}(1)$ and all four oxygen atoms $\mathrm{O}(1), \mathrm{O}(2), \mathrm{O}(3)$ and $\mathrm{O}(4)$, and is also linked to the second strontium metal atom through its fluorine atoms, $\mathrm{F}(2)$ and $\mathrm{F}(5)$, of the trifluoromethyl functional groups. Consequently, this is best described as a novel, $\mu-\eta^{6}$-type of coordination mode. Moreover, the $\mathrm{Sr}-\mathrm{O}$ distances of the bridging alkoxy oxygen atom, $\operatorname{Sr}(1)-\mathrm{O}(4)=2.538(3) \AA$ and $\operatorname{Sr}(1)-\mathrm{O}(4 \mathrm{~A})=2.524(3) \AA$, are significantly longer

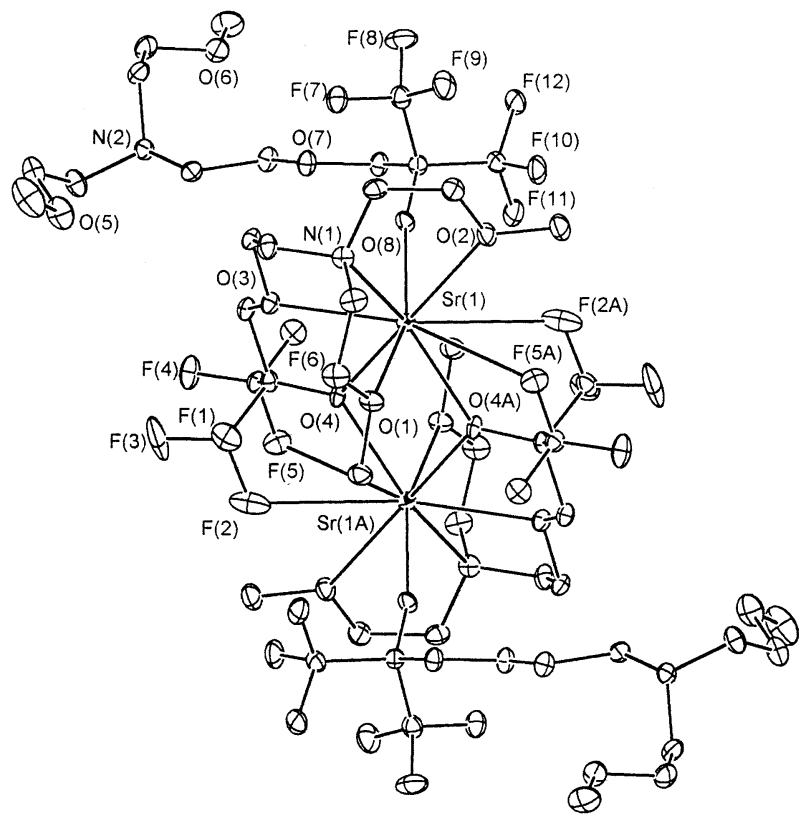

Fig. 3. ORTEP drawing of $\mathbf{3}$ with thermal ellipsoids shown at the $30 \%$ probability level. 


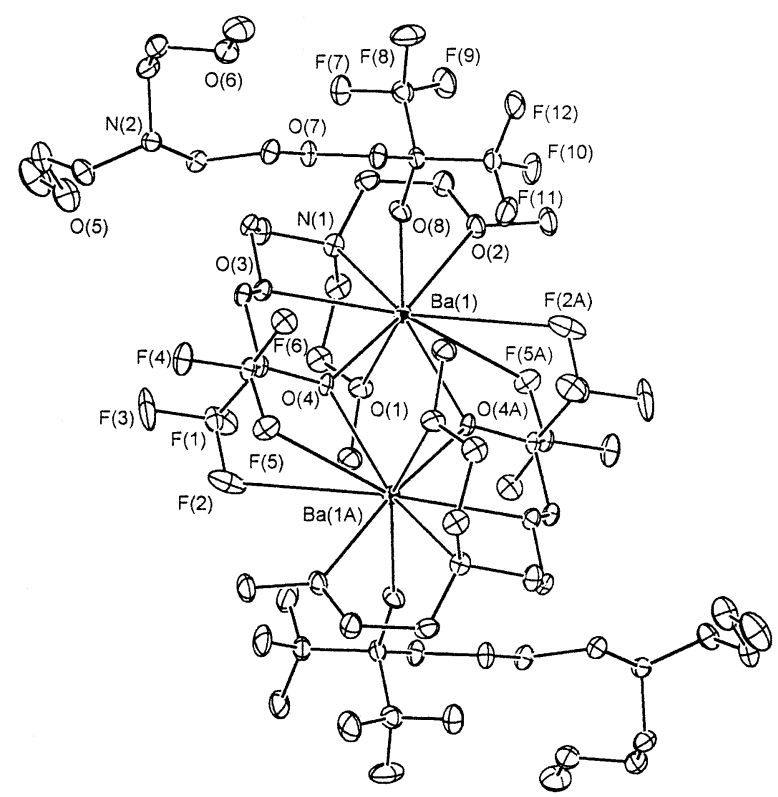

Fig. 4. ORTEP drawing of $\mathbf{4}$ with thermal ellipsoids shown at the $30 \%$ probability level.

than that of the terminal alkoxy O-atom $(\mathrm{Sr}(1)-\mathrm{O}(8)=$ $2.337(3) \AA$ ). This variation of the $\mathrm{Sr}-\mathrm{O}$ distances shows a stronger bonding interaction between the metal and the terminal alkoxy $\mathrm{O}(8)$ atom. The $\mathrm{O}($ ether $) \rightarrow \mathrm{Sr}$ dative distances, $\operatorname{Sr}(1)-\mathrm{O}(1)=2.655(3), \operatorname{Sr}(1)-\mathrm{O}(2)=2.830(3)$ and $\operatorname{Sr}(1)-\mathrm{O}(3)=2.632(3) \AA$, are found to vary irregularly, but they are all within the range as observed in the previously discussed mononuclear metal complex $\mathbf{1}$. Among these $\mathrm{Sr}-\mathrm{O}$ distances, the oxygen atom $\mathrm{O}(2)$ is only weakly coordinated to the $\mathrm{Sr}$ cation with respect to the other donor atoms $\mathrm{O}(1)$ and $\mathrm{O}(3)$. This may be caused by a competition exerted by the strongly coordinated alkoxy oxygen atom $\mathrm{O}(4)$, which is located at the trans-disposition to the methoxy oxygen atom $\mathrm{O}(2)$.

In addition, the nitrogen atom $\mathrm{N}(1)$ shows a fairly similar elongated distance of 2.835(4) $\AA$. This bond distance indicates an angle strain imposed by three adjacent $\mathrm{C}-\mathrm{C}-\mathrm{N}$ linkages, which prevents nitrogen atom from getting too close to the $\mathrm{Sr}$ atom. Finally, two fluorine atoms $F(5)$ and $F(2)$ are also found to reside at the positions very close to the nearby $\mathrm{Sr}$ atom, with $\operatorname{Sr}(1)-\mathrm{F}(5 \mathrm{~A})=3.140(4) \AA$ and $\operatorname{Sr}(1)-\mathrm{F}(2 \mathrm{~A})=$ 3.133(4) $\AA$. It is clear that these F..Sr distances are only slightly longer than the sum of the fluorine van der Waal's radius $(\sim 1.60 \AA)$ and the radius of $\mathrm{Sr}(+2)$ cation (1.32 ̊) [18], suggesting formation of a weak F...Sr dative interaction when they do exist in the solidstate.

The barium complex $\mathbf{4}$ is isostructural to that of $\mathbf{3}$, showing the similar distorted tricapped trigonal prismatic geometry for a total of nine-heteroatom coordination (Fig. 4). Again, the terminal alkoxy $\mathrm{Ba}(1)-\mathrm{O}(8)$ distance (2.468(4) $\AA$ ) is shorter than the bridging alkoxy $\mathrm{Ba}(1)-\mathrm{O}(4)$ bond distances 2.672(4) and 2.654(4) $\mathrm{A}$, while the latter is slightly shorter than the $\mathrm{Ba}-\mathrm{O}$ (ether) distances within this molecule $(2.816(4)-2.856(4) \AA)$. The $\mathrm{Ba}-\mathrm{O}$ (ether) distances observed in barium complex $\left[\mathrm{Ba}(\mathrm{dhd})_{2} \mathrm{CAP}-5\right] \quad(\mathrm{Ba}-\mathrm{O}($ ether $)=2.912(4)-2.970(5) \AA)$ also exhibits a similar geometry [19]. The formation of F...Ba dative interactions are clearly noted with distances $\mathrm{Ba}(1)-\mathrm{F}(2 \mathrm{~A})=3.358(6)$ and $\mathrm{Ba}(1)-\mathrm{F}(5 \mathrm{~A})=$ 3.212(4) $\AA$, which are comparable to the data reported in literature (2.87-3.29 $\AA$ ) [20,21] and, thus unambiguously confirm the involvement of the F..Ba dative interactions within the molecule.

\subsection{NMR studies}

As monomeric metal complexes $\mathbf{1}$ and $\mathbf{2}$ show a twofold rotational symmetry in the solid state, it implies that only one set of ${ }^{19} \mathrm{~F}$ NMR signal should be detected if their structures were maintained in the solution. The ${ }^{19} \mathrm{~F}$ NMR spectrum of complex 1 in $\mathrm{DMF}-\mathrm{d}_{7}$ at room temperature shows only one relatively sharp ${ }^{19} \mathrm{~F}$ NMR signal at $\delta-76.71$, which is somewhat consistent with this postulation. However, the ${ }^{19} \mathrm{~F}$ NMR spectrum recorded at $253 \mathrm{~K}$ exhibits one sharp signal at $\delta-$ 75.09 and two broad ${ }^{19} \mathrm{~F}$ NMR signals at $\delta-76.17$ and -76.75 with an approximate intensity ratio of 1:8:60. The first signal at $\delta-75.09$ is identified as the free ligand (meak)H, presumably generated by the reaction with small amount of water in $\mathrm{DMF}-\mathrm{d}_{7}$, as its ${ }^{19} \mathrm{~F}$ NMR chemical shift coincides with that of authentic sample. Thus the observation of the second and third signals gives a strong indication to the occurrence of two isomers undergoing rapid exchange.

Analogously, the barium metal complex 2 shows a broad ${ }^{19} \mathrm{~F}$ NMR signal at $\delta-76.71$ at $295 \mathrm{~K}$ in DMF$\mathrm{d}_{7}$. Upon lowering the temperature to $233 \mathrm{~K}$, this signal gradually de-coalesces to form one sharp signal at $\delta-$ 75.51 and two relative broad signals at $\delta-76.12$ and 76.76 with a ratio of $1: 4: 9$, showing a slowdown of the exchange process (Fig. 5). Again, the first signal at $\delta-$ 75.51 is due to the free ligand (meak) $\mathrm{H}$ generated by partial hydrolysis, and the other two signals are assigned as the time-averaged $\mathrm{CF}_{3}$ groups of the ligands derived from at least two distinct metal complexes. As such, it appears that both complexes $\mathbf{1}$ and $\mathbf{2}$ are stereochemically non-rigid on the NMR time scale, showing rapid exchange between hydrolyzed free ligand and two structurally unidentified isomers.

This fluxional behavior is also observed in the dimeric system. This is illustrated by the observation of one broad ${ }^{19} \mathrm{~F}$ NMR signal at $\delta-75.50$ due to the dissociated ligand (biak) $\mathrm{H}$ and a second signal at $\delta-$ 77.25 which are attributed to the $\mathrm{CF}_{3}$ groups of the $\mathrm{Sr}$ dimer complex 3 (Fig. 6). The broadening of these two peaks suggests the involvement of inter-exchange be- 


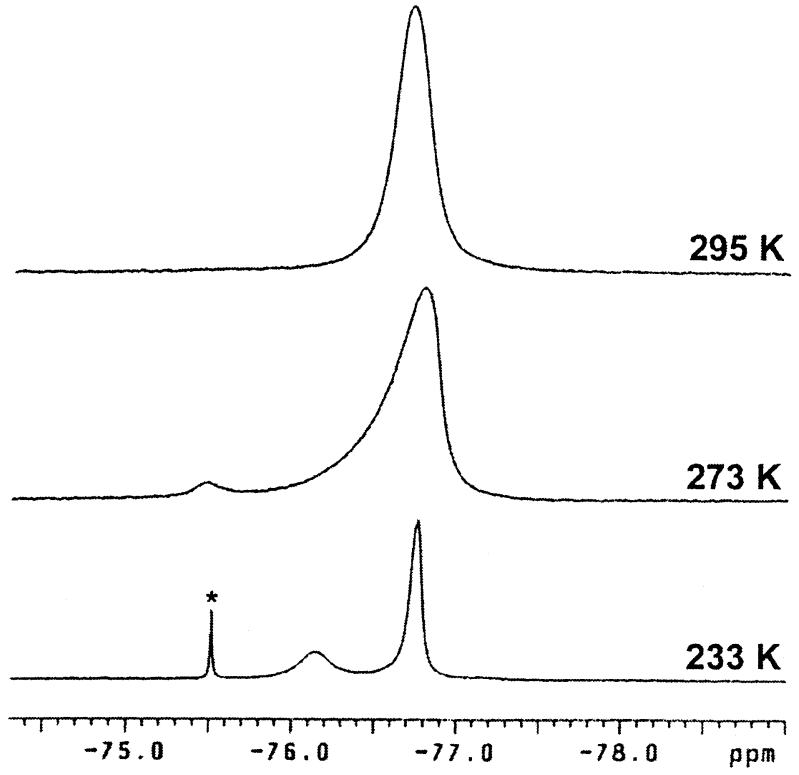

Fig. 5. VT ${ }^{19} \mathrm{~F}$ NMR spectra of 2 in DMF- $\mathrm{d}_{7}$; the signal marked with asterisk is due to free aminoalcohol (meak)H

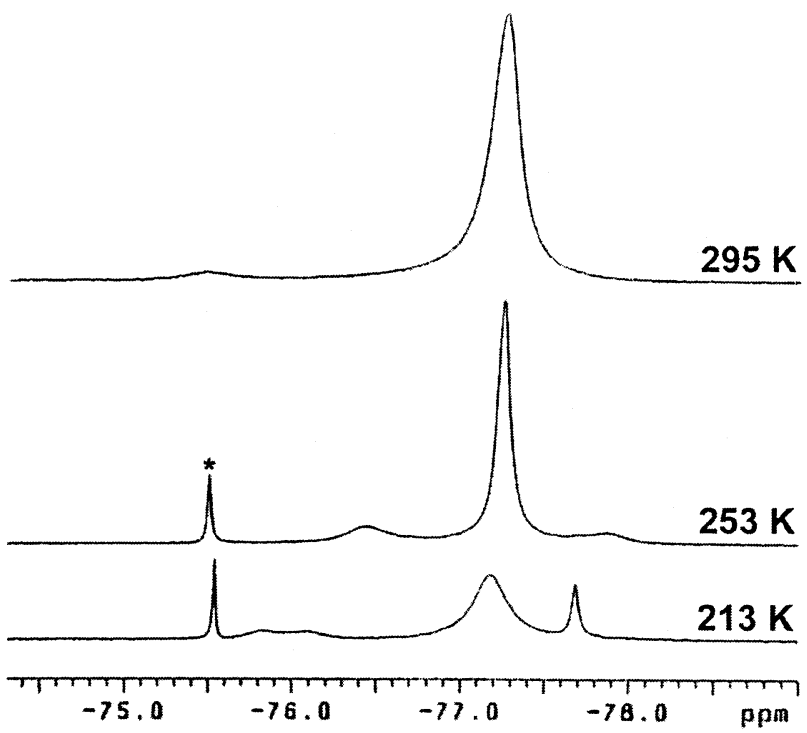

Fig. 6. VT ${ }^{19} \mathrm{~F}$ NMR spectra of $\mathbf{3}$ in $\mathrm{DMF}-\mathrm{d}_{7}$; the signal marked with asterisk is due to free aminoalcohol (biak)H.

tween the dissociated free ligand and the metal complex. Upon lowering the temperature to $253 \mathrm{~K}$, both signals turn much sharper and in the mean time, two weak signals are emerged from the baseline, one at $\delta-76.45$ and the second at $\delta-77.87$. By further decreasing the temperature to $213 \mathrm{~K}$, the signal at $\delta-76.45$ spilts into two relatively broad signals located at $\delta-75.80$ and 76.09 , while the second sharpens and shifts slightly to a new position at $\delta-77.68$. Because these three minor signals show an approximate ratio of $1: 1: 2$, it is clear that they are derived from a second, unknown structure, in which one alkoxide ligand shows a much larger kinetic barrier with respect to the movement of ligand on the coordination sphere, giving two magnetically non-equivalent $\mathrm{CF}_{3}$ groups.

The metal ion also influences the fluxional behavior of the dimer complex. This was shown by the detection of only one sharp signal at $\delta-77.17$ in the ${ }^{19} \mathrm{~F} \mathrm{NMR}$ spectrum of the barium complex 4 recorded in DMF- $\mathrm{d}_{7}$ at $295 \mathrm{~K}$. In contrast to that of the $\mathrm{Sr}$ complex 3 discussed earlier, this signal has turned slightly broader and moved to a high-field position at $\delta-77.64$ upon decreasing the temperature to $213 \mathrm{~K}$. Most importantly, no other signal was detected in this lower temperature limiting spectrum, except a signal assigned to a trace of the dissociated free ligand (biak)H. This observation is likely consistent with presence of one stereoisomer in DMF solution.

The variable temperature ${ }^{19} \mathrm{~F}$ NMR studies in a nonpolar toluene- $\mathrm{d}_{8}$ solvent were then examined to verify the exchange behavior that was not detected in DMF. To our surprise the spectrum at $295 \mathrm{~K}$ shows a set of four broad signals at $\delta-75.60,-76.10,-76.50$ and 76.76 and a fifth sharp signal located at $\delta-78.27$. As indicated in Fig. 7, the first four signals coalesce and merge into one signal at $\delta-76.23$ upon increasing the temperature to $333 \mathrm{~K}$. Upon lowering the temperature to $233 \mathrm{~K}$, they sharpen to give four ${ }^{19} \mathrm{~F}$ NMR signals with intensity ratio of $1: 1: 1: 1$, suggesting that these four signals are derived from a single isomer involving four non-equivalent $\mathrm{CF}_{3}$ groups within the molecule. On the other hand, the intensity of the fifth signal at $\delta-76.39$ turns much broader upon increasing the temperature to $333 \mathrm{~K}$, showing occurrence of the fast exchange with the

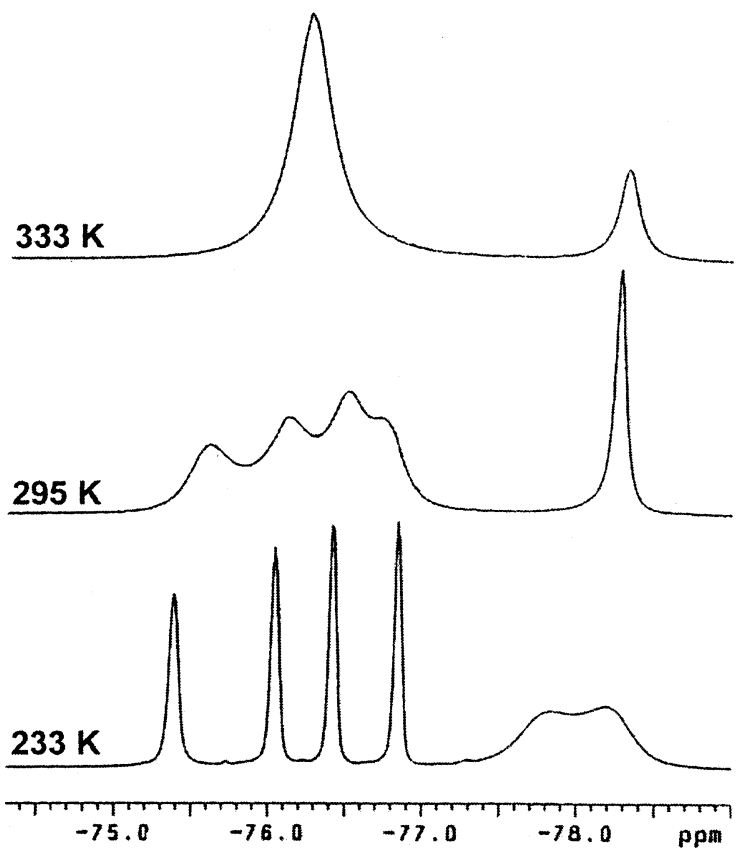

Fig. 7. VT ${ }^{19} \mathrm{~F}$ NMR spectra of $\mathbf{4}$ in toluene-d $\mathrm{d}_{8}$ solution. 
first isomer discussed. Upon lowering the temperature to $233 \mathrm{~K}$, this sharp signal broadens and splits into two equal intensity signals at $\delta-77.82$ and -78.19 , showing a slowdown of ligand movement on the coordination sphere. These data therefore are consistent with existence of two complexes in toluene, although their relationship cannot be fully identified.

\subsection{Volatility studies}

Physical properties relevant to the chemical vapor deposition studies were established. It showed that all complexes underwent sublimation without notable decomposition at $150{ }^{\circ} \mathrm{C}$ under a pressure of $200 \mathrm{mtorr}$ overnight, and the solid samples obtained before and after vacuum sublimation exhibited identical spectroscopic and physical characteristics. The behaviors of thermal decomposition were investigated by TG analysis in air with a flow rate of $100 \mathrm{sccm}$. As indicated in Fig. 8 , the rapid loss of weight started at $200{ }^{\circ} \mathrm{C}$, mainly due to sample decomposition. The residual weight then reached a steady value at approximately $300{ }^{\circ} \mathrm{C}$, giving off-white powdery materials $(\mathbf{1}, 20.6 ; \mathbf{2}, 22.4 ; \mathbf{3}, 17.1$; and 4, 19.6 wt.\%) upon further increasing the temperature to $450{ }^{\circ} \mathrm{C}$. Powder XRD analysis confirmed that these solid residues contain polycrystalline metal fluorides $\mathrm{SrF}_{2}$ and $\mathrm{BaF}_{2}$, respectively. The $\mathrm{TG}$ experiments that were carried out under nitrogen also produced similar pattern of weight loss, except that the residues appeared much darker and their XRD signals were slightly broader than those of the samples obtained in air, presumably due to the presence of the trace carbon impurity.

Preliminary CVD experiments were carried out to probe the possibility of depositing the $\mathrm{SrF}_{2}$ and $\mathrm{BaF}_{2}$ thin films from the fluoroalkoxide complexes 1-2, as their molecular weights are smaller and thus should be

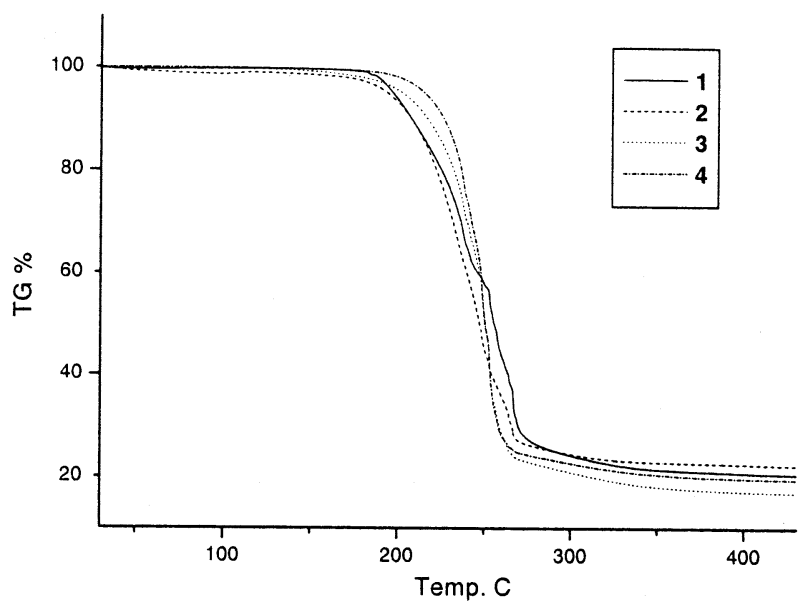

Fig. 8. Thermogravimetric analysis data for complexes $\mathbf{1 - 4}$ carried out in air $(100 \mathrm{sccm})$ with a heating rate of $10{ }^{\circ} \mathrm{C} \mathrm{min}^{-1}$. more volatile than the respective dimer complexes $\mathbf{3}$ and 4. Unfortunately, decomposition of source complexes was observed in the vaporization chamber maintained at $150{ }^{\circ} \mathrm{C}$, which is the lowest temperature required for the previous sublimation experiments. This low thermal stability has severely limited the vapor of complexes $\mathbf{1}$ or 2 that can be transported into the deposition chamber, and reduced the thickness of the as-deposited thin film on substrate surfaces. For the same reason, the XRD analysis of thin films has failed to show any obvious diffraction signals, which hampered the characterization.

\subsection{Summary}

Our results show that the designed synthesis of alkaline-earth metal fluoroalkoxide complexes has been achieved, for which their structures are solely determined by the arrangement of the ligand. For complexes $\mathbf{1}$ and 2, all four oxygen atoms of the ligand are coordinated to the metal cation, giving a distorted dodecahedral arrangement. Dissolution of these complexes in DMF solvent produces two isomeric species, which is revealed by the variable temperature ${ }^{19} \mathrm{~F}$ NMR examinations. The major isomer may possess the structure as determined by solid state X-ray diffraction experiment, while the minor isomer may adopt either a dimeric molecular structure related to $\mathbf{3}$ and $\mathbf{4}$, or a monomeric framework with a different spatial arrangement of alkoxide ligand or with a reversible coordination of polar DMF solvent. No definite conclusion about structure of the second isomer can be delineated based on our available data.

In contrast, X-ray structure analysis of complexes $\mathbf{3}$ and $\mathbf{4}$ revealed the dimeric structure, in which one type of alkoxide ligands is coordinated to both metal cations using all available hetero-atoms and two additional fluorine atoms, and the second alkoxide ligands is terminally coordinated to one metal. It is believed that coordination of the nitrogen atom of the $\mathrm{CH}_{2} \mathrm{~N}\left(\mathrm{CH}_{2} \mathrm{CH}_{2} \mathrm{OMe}\right)_{2}$ backbone, which is a much stronger Lewis base, has brought two oxygen atoms of the methoxyethyl groups to the vicinity of the metal cation, forming the energetically more favorable multiple coordinated interactions. As the coordination of all five heteroatoms and two fluorine atoms from the neighboring ligand has occupied almost all available coordination sites, it then forced the second alkoxide ligand to go terminal mode. Moreover, two rapid interconvertible isomers were also observed in polar and non-polar solution for $\mathbf{3}$ and $\mathbf{4}$, respectively, which may be attributed to the dimer-monomer equilibration or solvent incorporation into the metal center.

Finally, despite that these complexes are unsuitable for CVD applications due to the poor thermal stability as well as the low volatility, these complexes have shown 
very interesting structural diversity in both solid and solution. Therefore, their preparation and structural characterization should reap great benefit to the understanding of the traditional coordination chemistry of strontium and barium alkoxide complexes.

\section{Supplementary material}

Crystallographic data for the structural analysis have been deposited with the Cambridge Crystallographic Data Centre, CCDC Nos. 176903, 176904, 176905, 176906 for complexes 1, 2, 3, 4, respectively. Copies of this information may be obtained free of charge from The Director, CCDC, 12 Union Road, Cambridge, CB2 1EZ, UK (fax: +44-1223-336-033; e-mail: deposit@ccdc.cam.ac.uk or www: http://www.ccdc.cam.ac.uk).

\section{Acknowledgements}

We thank the National Science Council, Taiwan, Republic of China for funding (Grant No. NSC 892113-M-007-034).

\section{References}

[1] (a) D.G. Gilliland, M.L. Hitchman, S.C. Thompson, D.J. ColeHamilton, J. Phys. III 2 (1992) 1381;

(b) M. Tiitta, L. Niinistö, Chem. Vap. Deposition 3 (1997) 167; (c) J.A.P. Nash, J.C. Barnes, D.J. Cole-Hamilton, B.C. Richards, S.L. Cook, M.L. Hitchman, Adv. Mater. Opt. Electron. 5 (1995) 1 ;

(d) A.C. Jones, Chem. Vap. Depos. 4 (1998) 169;

(e) W. Clegg, S.J. Coles, E.K. Cope, F.S. Mair, Angew. Chem., Int. Ed. Engl. 37 (1998) 796.

[2] (a) A.P. Purdy, A.D. Berry, R.T. Holm, M. Fatemi, D.K. Gaskill, Inorg. Chem. 28 (1989) 2799;

(b) S. Sinharoy, Thin Solid Films 187 (1990) 231;

(c) H. Sato, S. Sugawara, Inorg. Chem. 32 (1993) 1941;

(d) E. Daran, L.E. Bausa, A. Muñoz-Yagüe, C. Fontaine, Appl. Phys. Lett. 62 (1993) 2616;

(e) H. Sato, Jpn. J. Appl. Phys. 33 (1994) L368;

(f) O. Poncelet, J. Guilment, D. Martin, J. Sol-Gel Sci. Technol. 13 (1998) 129.

[3] (a) W.S. Rees, Jr., M.W. Carris, W. Hesse, Inorg. Chem. 30 (1991) 4479 ;

(b) J.A.T. Norman, G.P. Pez, J. Chem. Soc., Chem. Commun. (1991) 971;

(c) G. Rossetto, A. Polo, F. Benetollo, M. Porchia, P. Zanella, Polyhedron 11 (1992) 979;

(d) S.R. Drake, M.B. Hursthouse, K.M.A. Malik, S.A.S. Miller, J. Chem. Soc., Chem. Commun. (1993) 478;

(e) W.A. Wojtczak, M.J. Hampden-Smith, E.N. Duesler, Inorg. Chem. 37 (1998) 1781.

[4] (a) W.S. Rees, Jr., D.A. Moreno, J. Chem. Soc., Chem. Commun. (1991) 1759

(b) D.L. Schulz, B.J. Hinds, D.A. Neumayer, C.L. Stern, T.J Marks, Chem. Mater. 5 (1993) 1605; (c) L.G. Hubert-Pfalzgraf, F. Labrize, C. Bois, J. Vaissermann, Polyhedron 13 (1994) 2163;

(d) A.M. Bahl, S. Krishnaswamy, N.G. Massand, D.J. Burkey, T.P. Hanusa, Inorg. Chem. 36 (1997) 5413;

(e) S.L. Castro, O. Just, W.S. Rees, Jr., Angew. Chem., Int. Ed. Engl. 39 (2000) 933.

[5] (a) G.M. Sheldrick, SHELXTL version 5.10, Siemens Analytical Xray Instruments Inc., Madison, WI, USA, 1998;

(b) Siemens, SMART and SAINT, Siemens Analytical X-ray Instruments Inc., Madison, WI, USA, 1995;

(c) G.M. Sheldrick, SADABS, University of Göttingen, Göttingen, Germany, 1996.

[6] I.-S. Chang, C.J. Willis, Can. J. Chem. 55 (1977) 2465.

[7] (a) Y. Chi, S. Ranjan, T.-Y. Chou, C.-S. Liu, S.-M. Peng, G.-H. Lee, J. Chem. Soc., Dalton Trans. (2001) 2462;

(b) P.-F. Hsu, Y. Chi, T.-W. Lin, C.-S. Liu, A.J. Carty, S.-M. Peng, Chem. Vap. Depos. 7 (2001) 28.

[8] J.W. Park, J.T. Kim, S.M. Koo, C.G. Kim, Y.S. Kim, Polyhedron 19 (2000) 2547.

[9] J.A. Darr, S.R. Drake, M.B. Hursthouse, K.M.A. Malik, S.A.S. Miller, D.M.P. Mingos, J. Chem. Soc., Dalton Trans. (1997) 947.

[10] Y. Shen, Y. Pan, G. Dong, X. Sun, X. Huang, Polyhedron 17 (1998) 69

[11] D.J. Otway, W.S. Rees, Jr., Coord. Chem. Rev. 210 (2000) 279 (and references therein).

[12] S.R. Drake, M.B. Hursthouse, K.M.A. Malik, D.J. Otway, J. Chem. Soc., Dalton Trans. (1993) 2883.

[13] S.R. Drake, M.H. Chisholm, K.G. Caulton, K. Folting, Inorg. Chem. 29 (1990) 2707.

[14] (a) R. Gardiner, D.W. Brown, P.S. Kirlin, A.L. Rheingold, Chem. Mater. 3 (1991) 1053;

(b) S.R. Drake, S.A.S. Miller, D.J. Williams, Inorg. Chem. 32 (1993) 3227;

(c) S.R. Drake, M.B. Hursthouse, K.M.A. Malik, S.A.S. Miller, D.J. Otway, Inorg. Chem. 32 (1993) 4464;

(d) D.A. Neumayer, D.B. Studebaker, B.J. Hinds, C.L. Stern, T.J. Marks, Chem. Mater. 6 (1994) 878;

(e) M. Motevalli, P. O'Brien, I.M. Watson, Acta Crystallogr. C52 (1996) 3028;

(f) J.A. Belot, D.A. Neumayer, C.J. Reedy, D.B. Studebaker, B.J. Hinds, C.L. Stern, T.J. Marks, Chem. Mater. 9 (1997) 1638.

[15] (a) K.G. Caulton, M.H. Chisholm, S.R. Drake, J.C. Huffmann, J. Chem. Soc., Chem. Commun. (1990) 1498;

(b) O. Poncelet, L.G. Hubert-Pfalzgraf, L. Toupet, J.C. Daran, Polyhedron 10 (1991) 2045;

(c) A.P. Purdy, C.F. George, J.H. Callahan, Inorg. Chem. 30 (1991) 2812;

(d) B. Borup, J.A. Samuels, W.E. Streib, K.G. Caulton, Inorg. Chem. 33 (1994) 994;

(e) H. Vincent, F. Labrize, L.G. Hubert-Pfalzgraf, Polyhedron 13 (1994) 3323.

[16] S.R. Drake, W.E. Streib, K. Folting, M.H. Chisholm, K.G. Caulton, Inorg. Chem. 31 (1992) 3205.

[17] P. Miele, J.D. Foulon, N. Hovnanian, L. Cot, Polyhedron 12 (1993) 267.

[18] L. Pauling, The Nature of the Chemical Bond, 3rd ed., Cornell University Press, Ithaca, NY, 1960, p. 256.

[19] D.B. Studebaker, D.A. Neumayer, B.J. Hinds, C.L. Stern, T.J. Marks, Inorg. Chem. 39 (2000) 3148.

[20] (a) A.P. Purdy, C.F. George, Inorg. Chem. 30 (1991) 1970;

(b) J.A. Samuels, E.B. Lobkovsky, W.E. Streib, K. Folting, J.C. Hoffman, J.W. Zwanziger, K.G. Caulton, J. Am. Chem. Soc. 115 (1993) 5093;

(c) F. Labrize, L.G. Hubert-Pfalzgraf, J.C. Daran, S. Halut, J. Chem. Soc., Chem. Commun. (1993) 1556; 
(d) A.P. Purdy, C.F. George, ACS Symp. Ser. 555 (1994) 405;

(e) A. Drozov, A. Pozhitkov, S. Troyanov, A. Pisarevsky, Polyhedron 15 (1996) 1731;

(f) L.G. Hubert-Pfalzgraf, Coord. Chem. Rev. 178-180 (1998) 967; (g) Y. Chi, S. Ranjan, P.-W. Chung, C.-S. Liu, S.-M. Peng, G.-H. Lee, J. Chem. Soc., Dalton Trans. (2000) 343.

[21] D.C. Bradley, M. Hasan, M.B. Hursthouse, M. Motevalli, O.F.Z. Khan, R.G. Pritchard, J.O. Williams, J. Chem. Soc., Chem. Commun. (1992) 575. 